Kansas State University Libraries

New Prairie Press

\title{
MULTIPLE REGRESSION ANALYSIS OF SOIL PROPERTIES ON ERODED AND NATIVE DEEP LOESS MISSOURI SOILS
}

S. J. Indorante

J. M. Maatta

R. D. Hammer

J. R. Brown

See next page for additional authors

Follow this and additional works at: https://newprairiepress.org/agstatconference

Part of the Agriculture Commons, and the Applied Statistics Commons

\section{(c) (1) $\Theta(9$}

This work is licensed under a Creative Commons Attribution-Noncommercial-No Derivative Works 4.0 License.

\section{Recommended Citation}

Indorante, S. J.; Maatta, J. M.; Hammer, R. D.; and Brown, J. R. (1989). "MULTIPLE REGRESSION ANALYSIS OF SOIL PROPERTIES ON ERODED AND NATIVE DEEP LOESS MISSOURI SOILS," Conference on Applied Statistics in Agriculture. https://doi.org/10.4148/2475-7772.1456

This is brought to you for free and open access by the Conferences at New Prairie Press. It has been accepted for inclusion in Conference on Applied Statistics in Agriculture by an authorized administrator of New Prairie Press. For more information, please contact cads@k-state.edu. 


\section{Author Information}

S. J. Indorante, J. M. Maatta, R. D. Hammer, and J. R. Brown 


\title{
MUITIPIE REGRESSION RNALYSIS OF SOII PROPERTIES ON ERODED AND NATIVE DEEP IOESS MISSOURI SOIIS
}

\author{
S.J. Indorante ${ }^{1}$, J.M. Maatta ${ }^{2}$, R.D. Hammer ${ }^{1}$, and J.R. Brown ${ }^{1}$ \\ 1 Department of Agronomy 2Department of Statistics \\ University of Missouri, Columbia 65211
}

\begin{abstract}
Researchers have described the difficulty of studying the effects of cultivation on soil properties unless native (uncultivated) areas can be used as a baseline for comparison. Even when suitable areas are located the problems of quantifying and comparing the horizontal and vertical distributions of soil properties remain. Areal distributions of soil surface, subsurface, and upper subsoil properties were compared in cultivated and forested deep loess soils on similar geomorphic surfaces and hillslope positions in two counties adjacent to the Missouri River. A 3-dimensional grid was used to sample selected soils from the summit to the lower backslope on 3 forested and 3 cultivated hillslopes. Multiple regression analysis revealed that a second order response surface equation adequately modeled the depths to maximum clay percentage and thickness of "A" horizon and a third-order response surface adequately modeled thickness of the subsurface horizon and depth to top of "B" horizon, based on the independent variables percent slope, distance from hillslope summit, and site management. Further analysis showed that each site had a significantly different response surface which could be related to site characteristics and current cover (forest or cultivation). The use of analysis of variance within multiple regression allowed for the systematic description and comparison of soil properties on forested and cultivated sites, and for the determination of the relationship between the selected soil properties and slope and site characteristics.
\end{abstract}

Key Words: hillslope modeling, response surface methodology, soil variability.

\section{INTRODUCTION}

Quantification and prediction of soil heterogeneity are among the most important challenges to pedologists. Agronomists have commonly used blocking and replication in experiments with analysis of variance (ANOVA) statistics to extract soil variance from crop yield experiments (Wilding and Drees, 1983). The heterogeneity of soil properties important to the experimental units, experimental plot size, and the sensitivity of experimental units can limit the effectiveness of ANOVA designs in soil-based research. Figure 1 demonstrates the failure of blocking to extract the range in thickness of the "A" horizon within three phases of a soil series. Such approaches attempt to minimize the effects of soil variability on the experiment, but do not improve the researchers' abilities to predict either 
occurrence of the soil variability or the impact of soil variability on the experimental unit.

Determining the effects of soils and their landscape occurence on crop yield remains among the foremost challenges facing soil scientists and agronomists. Of particular importance is the difficulty in assessing the true impact of soil erosion on crop yield. Daniels et al., (1987) stated that the heterogeneity in crop yield within sloping fields is often blamed on erosion and sedimentation when native heterogeneity of soil properties and the consequent variability of plantavailable water may be the primary causal agents. Percent slope and distance from summit affect soil properties in sloping landscapes (Kleiss, 1970; Ruhe, 1969; Ruhe and walker, 1968; Walker and Ruhe, 1968), but the difficulty in separating the effects of soil erosion from soil heterogeneity on yield is compounded because few virgin soils are available for study. Mermut et al., (1983) compared native grassland and cultivated sites in Canada and reported cultivation was the most important factor in producing soil variability between grassland and cultivated sites.

Many researchers (Kleiss, 1970; Ruhe, 1969; Ruhe and Walker, 1968; Walker and Ruhe, 1968) have shown that multiple regression is well suited for the study of the relationship between visible landscape features (such as percent slope and distance from summit) and surface and subsoil features. The determination of soil-landscape relationships is central to the making of accurate soil surveys and accurate descriptions of the effects of man-induced erosion on the soil.

With soil variability being such an over-riding factor, any attempt to fit a mechanistic model to landscape variables would be fruitless. Our choice thus falls to empirical model-building and response surface methodology (RSM). The present study incorporates these methods within multiple linear regression to first determine the relationship between landscape features, percent slope and distance from summit, and upper soil profile properties, and then determine the effects of cultivation on these soil properties. Percent slope and distance from slope summit were chosen as variables because previous studies indicate they influence soil properties on sloping landscapes (mentioned above) and because they are predominate features on sloping landscapes. Previous studies are deficient since they fail to incorporate both landscape factors and cultivation factors in their models. Cultivation factors are entered into our model via the careful selection of similar sites along the Missouri River. These sites are similar soil series with comparable, slope aspect, elevation, and slope shape. (see section III for complete description.) The predominate difference is past cultivation practice. If sites are significantly different, one can infer the effects of cultivation on upper soil profile properties.

The objective of this study was to measure and compare the distribution of soil properties in virgin (native) and 
cultivated deep loess soils on similar landscapes. Important factors include determining the degree of importance of the landscape variables in explaining soil variation, selecting specific models from candidate models to describe horizontal and vertical distribution of soil properties across the landscape, and predicting surface and subsoil properties from visible landscape features.

\section{METBODS}

Site selection -- Six study sites were selected, four in Saline County, Missouri and two in Boone County, Missouri. All sites were on the thick loess bluffs adjacent to the Missouri River. The sites were similar in distance and direction from the loess source, and were similar in aspect, elevation, and slope shape. Two saline county sites were forested, and two sites have been cultivated since the early 1900's. All four sites were mapped as a phase of the knox series (fine-silty, mixed, mesic Mollic Hapludalfs). One Boone county site was undisturbed forest and one site has been cultivated since the early 1900's. Both sites were mapped as a phase of the Menfro series (fine-silty, mixed mesic Typic Hapludalfs). At each site, the portion of the hillslope studied included the summit, shoulder, and backslope components. Slope steepness ranged from 0 to $34 \%$. The Saline county sites are designated as Van Meter 1, Van Meter 2, Dysart, and Holland. Van Meter 1 was mixed hardwood forest dominated by early successional species in the canopy. Historical records indicated that the site was in prairie in the early $1800^{\prime} \mathrm{s}$. Van Meter 2 is similar to Van Meter 1 except for evidence of historical Indian settlement. The Dysart and Holland sites have been cultivated since the early 1900 's and are located near the van Meter sites. The Boone county sites are Schnabel, a mixed hardwood forest, and McBain, which has been cultivated since the early 1900's and is located near the Schnabel site.

Field Sampling -- At each site an equal density grid was established from the middle of the hillslope summit to the lower backslope. The sites were $10 \mathrm{~m}$ wide and typically $65 \mathrm{~m}$ in length and crossed normal to the contour of the slopes. Flags were placed at meter intervals. Grid points were designated as combinations of column and row number. Columns were oriented downslope, normal to the contour; rows were parallel to the contour. Elevations were taken at each grid point. Cores were taken to a depth of $110 \mathrm{~cm}$ at $6 \mathrm{~m}$ intervals down columns number $2,4,6$, and 8 . The cores were described by standard nomenclature (Soil survey Staff, 1981). The cores, to the top of the $B$ horizon, were segmented and sampled by horizon. The cores, from the top of the $B$ horizon to the bottom of the cores, were segmented and sampled in $10 \mathrm{~cm}$ increments.

Slope Parameters Measured -- Distance from the middle of hillslope summit was determined from the grid and percent slope was calculated from the elevation data for each sampling point.

Soil Variables Measured -- The surface ("A" horizon), subsurface ("E", "AB", "EB", and "BE"), and upper subsoil ("B" 
horizon) properties of interest were: depth to maximum clay percentage; thickness of "A" horizon; subsurface horizon thickness (if present); and depth to top of "B" horizon. These properties are commonly used as guidelines for recognizing and naming phases of eroded soils (Soil Survey Staff, 1981).

Laboratory procedures -- The samples were air-dried and crushed to pass through a $2 \mathrm{~mm}$ sieve. Clay percentage was determined by the Follmer procedure (Indorante et. al., in press) and the horizon locations and thicknesses were taken from the core descriptions (Soil Survey Staff, 1981).

statistical Methods -- Empirical model building and response surface methodology were utilized to study the relationships between selected soil properties and hillslope and site variables. In particular, interest lies in modeling depth to maximum clay percentage $(\mathrm{cm})$, Yd; depth to top of "B" horizon $(\mathrm{cm}), Y_{b}$; thickness of subsurface horizon $(\mathrm{cm}), Y_{e} ;$ and thickness of "A" horizons $(\mathrm{cm}), Y_{a}$; as a function of percent slope, $X_{1}$; distance from summit of slope $(m), X_{2}$; and site ( $X_{3}$ through $\left.\mathrm{X}_{7}\right)$, appropriately coded as 0 or 1 .

The choice of an empirical model to approximate (at least locally) the unknown mechanistic model is a most complex problem. It is generally thought that a simple polynomial model would adequately model the unknown mechanistic model (see Box and Draper, 1987), particularly if the system itself is quite complex, but assumed to be smooth. The existence of extreme soil variability alone suggests the complexity of the system. In addition, there are many other factors that add to the complexity. Thus, for our problem it was felt that the most simple empirical model (i.e. a polynomial), would be an adequate first step in explaining the soil variability in the system. Furthermore, as often the practice, a polynomial of at most second-order was felt to be the model that might adequately and simply represent the true response. However, to guard against any significant inadequacy of fit, a third-order polynomial model was fit and it's third-order terms tested simultaneously via the general linear test (GIT). Thus we envision a sequence of models as follows:

\section{First-order/second-order/third-order}

Where each submodel included the appropriate order independent variables $x_{1}, \ldots, x_{7}$. Our goal was to choose, for each soil property, the most simple adequate model for that property. Each submodel was tested versus the next more general model (first-order versus second-order, for example) by simultaneously testing the additional terms in the more general model. It is important to note here that this addition or deletion of terms is considered simultaneously, as is often the practice when fitting polynomial models (Box and Draper, 1987).

As a first step, a third-order polynomial response surface was fit by the PROC REG procedure within the SAS system (SAS 
Inst. Inc., 1985b) for each dependent variable:

$$
E(Y)=\beta_{0}+\sum_{i=1}^{7} \beta_{i} x_{i}+\sum_{i=1}^{2} \sum_{j=1}^{7} \beta_{i j} x_{i} x_{j}+\sum_{i=1}^{2} \sum_{j=1}^{2} \sum_{k=1}^{7} \beta_{i j k} X_{i} x_{j} X_{k}[2]
$$

where $Y$ is the selected soil variable, and $X_{1}$ through $X_{7}$ are defined as above, with the additional squared, cubic, and interaction terms. If the overall third-order model was found to be significant, the GLT was applied to test the significance of the third-order terms. If third-order terms were not significant, the terms were dropped and the second-order model was fit as follows:

$$
E(Y)=\beta_{0}+\sum_{i=1}^{7} \beta_{i} x_{i}+\sum_{i=1}^{2} \sum_{j=1}^{7} \beta_{i j} x_{i} X_{j}
$$

In addition, the significance of the second-order terms were tested versus a first-order model:

$$
E(Y)=\beta_{0}+\sum_{i=1}^{7} \beta_{i} x_{i}
$$

Following the fitting of the potential model in [1], the GIT was again applied to determine if sites (cultivation practices) were significantly different for the particular dependent variable. Thus, within any particular order model we can envision another sequence of models represented by:

\section{all sites the same/ forested sites different from cultivated sites/ all sites different}

Depending on the results of this test, equations for each site were generated using the appropriate site coding. Response surfaces were generated using PROC GBD procedure in SAS/GRAPH (SAS Inst. Inc, 1985a).

\section{RESULTS and DISCUSSION}

\section{A) Statistical Results}

The results of the general linear tests are summarized in table 1 and the subsequent response surface equations are given in table 2. Depths to clay maxima and "A" horizon thickness were adequately modeled by second-order response surfaces. Subsurface horizon thicknesses and depths to top of "B" horizon were adequately modeled by third-order response surfaces (Table 
1). These results were obtained via the application of the GIT to test various models within the model sequence [1]. For example, for depths to clay maxima the test of the third-order versus second order model resulted in the failure to reject the null hypothesis Ho: all third-order $B^{\prime} s=0$, resulting in the tentative acceptance of the second-order model as adequate. A repeat of the GIT testing was done for clay maxima resulting in the rejection of the null hypothesis Ho: all second-order $B$ ' $S=0$, resulting in a fit of the second-order polynomial model. similar tests were performed for each soil property and are summarized in table 1.

The next stage was to test, via the GLT, whether the inclusion of the site indicator variable explained a significant proportion of the variability of a given soil property. The sequential nature of the models under consideration is given in [5]. The first step was to determine whether forested sites were significantly different from cultivated sites. The hypothesis of interest was whether the appropriate site regression coefficients were simultaneously zero or not. As was to be expected, it was the case for all soil properties that forested sites were significantly different from cultivated. This result predicated the next step: testing whether all sites were significantly different. Again the hypothesis of interest involved the appropriate site regression coefficients. As summarized in table 1 , the results of the GIT indicated that we could reject the null hypothesis and accept the most general model in sequence [5], i.e. all sites significantly different (alpha=.05). Table 2 displays the fitted second and third-order response model for the various soil properties and reflects the influence found by the significant site indicators.

Figure 2 shows the depths to clay maxima second-order response surface for the forested Van Meter 2 site in Saline county. The plotted response surfaces graphically show how the selected soil characteristics vary with percent slope, distance from slope summit and site, and also the area of interpretive interest.

Soil characteristic calculations from the response surface equations for combinations of slope and distance from summit for each site, are given in table 3. The three combinations of slope and distance from summit for each site represent actual points on the summit, shoulder, and backslope portions. All four soil characteristics vary with percent slope and distance from summit (hillslope position) for all six sites (Table 2). The depth to clay maximum data, for all sites, was more variable than "A" horizon thickness, subsurface horizon thickness, and depth to top of "B", as shown by the confidence intervals in Table 3 and ranges and standard deviations in Table 4.

The means, ranges, and standard deviations of the four soil characteristics for each site by slope position are given in Table 4. The univariate statistics (Table 4) show the distribution of soil characterististics on each hillslope component and the relationship between each hillslope component and soil property. Soil characteristics vary by slope position 
(which is a function of percent slope and distance from summit), but vary in a systematic and predictable manner downslope from summit to shoulder to backslope.

\section{B) Soil Properties}

Results from the response surface equations from the forested sites(Table 3) show that depths to clay maxima increases from the summit to the shoulder, and with the exception of the van Meter 2 site, became shallower from the shoulder to the backslope. Depths to clay maxima on the cultivated sites, decreased from the summit to the backslope on the McBain site; increased for the Dysart site, and increased from the summit to the shoulder; then decreased from shoulder to backslope for the Holland site.

Increased depths to clay maxima, from shoulder to backslope, for the Van Meter 2 and Dysart sites may be due to downslope soil movement. Soil disturbance during Indian settlement may have enhanced soil movement and deposition on van Meter 2. Cultivation and erosion are the most likely causes on Dysart. Downslope soil movement increased depths to clay maxima on the lower parts of the slope. At the saline county sites, depths to clay maxima were shallower for the cultivated sites than for the forested sites on all slope positions. The largest differences (forested depth minus cultivated depth) are: on the summit $(44.76 \mathrm{~cm}$ shallower); on the shoulder $(33.13 \mathrm{~cm}$ shallower); and on the backslope (49.17 $\mathrm{cm}$ shallower). In Boone County, the depths to clay maxima for the Schnabel site were slightly shallower than the McBain site on the summit. The McBain cultivated site was $8.66 \mathrm{~cm}$ shallower on the shoulder position and $13.25 \mathrm{~cm}$ shallower on the backslope position than the forested Schnabel site.

"A" horizons became thinner from the summit to the backslope on all sites except the Dysart site, where this horizon thinned from summit to shoulder, then thickened slighty from shoulder to backslope (Table 3). The Dysart site showed strong evidence of accelerated soil erosion from cultivation. On most sites the systematic "A" horizon thinning downslope is approximately 2 times greater from the shoulder to the backslope than from summit to shoulder. The "A" horizon, as applied to cultivated sites, is descriptive rather than functional, because the "A" horizon is the plow layer. As such, it may include "A", "E", or parts of the "B" horizons. The natural thinning or absence of transition horizons and decrease in the depth to top of "B" horizon downslope contribute to the incorporation of subsoil material into the "Ap" horizon. The cultivated sites show a rapid thinning or absence of subsurface horizons from the summit to the backslope. The most dramatic thinning occurs on the shoulders and backslopes.

The forested sites show an increase in subsurface horizon thickness from the summit to the shoulder (Table 3). From the shoulder to the backslope of Van Meter 1 subsurface horizon thickness increases, but decreases for the Van Meter 2 and schnabel sites. The thickest subsurface horizons were on the 
nearly level, stable part of the hillslopes, where little or no erosion had occurred. Thinner subsurface horizons occurred on the sloping, unstable parts of the landscape.

Depth to the top of "B" horizon decreased from the summit to the shoulder for Van Meter 1, and increased for Van Meter 2 and for Schnabel (Table 3). The depth to top of the "B" horizon decreased from the shoulder to the backslope. All three cultivated sites showed a marked decrease in depth to top of "B" horizon, from the summit to the shoulder. Truncation of the surface and subsurface horizons is due to accelerated erosion.

\section{SUMMARY and CONCLUSIONS}

The use of analysis of variance within multiple regression allowed the systematic description and comparison of soil properties on forested and cultivated sites. Relationships between the selected soil properties and slope and site characteristics were identified. The fitted response surface models for each soil characteristic support the hypothesis that the soil characteristics are related to percent slope and distance from summit (slope position). A different response surface for each site for each soil characteristic supports the hypothesis that vegetative history and cultivation had a significant effect on the distribution of these soil properties down a hillslope, and that these soil properties change in a systematic and predictable manner.

The biggest difference among sites can be seen when comparing the forested to the cultivated sites. Within site variability of individual soil properties occlude interpretations, but by assessing the properties together, a pattern of landscape evolution and accelerated soil erosion becomes apparent. The shallower depths to clay maxima, thinner or absent subsurface horizons, and shallower depth to top of "B" horizons are evidence that the upper horizons of cultivated soils have been disturbed and mixed. Subsequent truncation resulted from long term cultivation. The differences between forested and cultivated sites suggest the progressive lowering of the boundary of the plowed layer or tilled zone into the subsoil due to soil erosion and tillage.

The soil-hillslope system is very complex. This study utilized empirical model building and response surface methodology in an attempt to determine the distribution of key soil properties in forested and cultivated hillslopes. Models of the system should be carefully interpreted in conjunction with on-site evaluations. The distribution and variability of soils across a landscape (or down a hillslope) are largely controlled by five major factors: climate; biotic activities such as vegetation and organisms (including man), topography, parent material and time (Jenny, 1941). To better understand the effects of cultivation on the soil, this study attempted to find sites that were similar in climate, topography, parent material, and time. However, even with careful site selection a large amount of undescribed soil variability still exists in both 
forested and cultivated hillslopes, suggesting that many other variables related to the soil forming factors should be considered in this type of model building.

\section{REEERENCES}

Box, G.E.P.and N.R. Draper. 1987. Empirical model building and response surfaces. John Wiley and Sons. New York.

Daniels, R.B., J.W. Gilliam, D.K. Cassel, and I.A. Nelson. 1987. Quantifying the effects of past soil erosion on present soil productivity. J. of Soil and Water Conservation $42: 183-187$.

Indorante, S.J., I.R. Follmer, R.D. Hammer, and P.G. Koenig. 1990. A modified pipette procedure for particle size analysis. Soil Sci. Soc. Am. J. (In press).

Jenny, H. 1941. Factors of soil formation. McGraw-Hill Book Company Inc. NY.

Kleiss, H.J. 1970. Hillslope sedimentation and soil formation in Northeastern Iowa. Soil Sci. Soc. Amer. Proc. 34:287-290.

Mermut, A.R., D.F. Acton, and W.D. Eilers. 1983. Estimation of soil erosion and deposition by a landscape analysis technique on clay soils in southwestern Saskatchewan. Can. J. Soil Sci. $63: 727-739$.

Ruhe, R.V., 1969. Quaternary landscapes in Iowa. Iowa State Uni. Press, Ames, IA.

Ruhe, R.V. and P.H. Walker. 1968. Hillslope models and soil formation. I. open systems. Trans. 9th Cong. Int. Soil sci. Soc., Adelaide, iv, 551-560.

SAS Institute Inc. 1985a. SAS/GRAPH user's guide, Version 5 ed., Cary, NC.

SAS Institute Inc. 1985b. SAS user's guide:statistics, Version 5 ed., Cary, NC.

Soil Survey Staff. 1981. Soil survey manual . U.S.Dep. Agric. Handb. 18.

walker, P.H. and R.V. Ruhe. 1968. Hillslope models and soil formation. II. Closed systems. Int.Congr. of Soil Sci., Trans. 9th (Adelaide, Aust.), IV:561-568.

Wilding, L.P. and L.R. Drees. 1983. Spatial variability and pedology. P. 83-116. In. L.P. Wilding, N.E. Smeck, and G.F. Hall (ed.). Pedogenesis and soil taxonomy. Elsevier Press.

\section{ACKNOWLEDGEMENTS}

Contribution from the Missouri Agr. Exp. St. Jour. Series \# 10,929 .

This project was supported by funds provided by the Missouri Dept. of Natural Resources through grant contract 86-2. Special thanks to Margie Gurwit, UMC, SAS Consultant. 
50 MPPNO UNT

(PHASE OF A SOIL SERIES) PATIEANS NA CULTNATEO FED

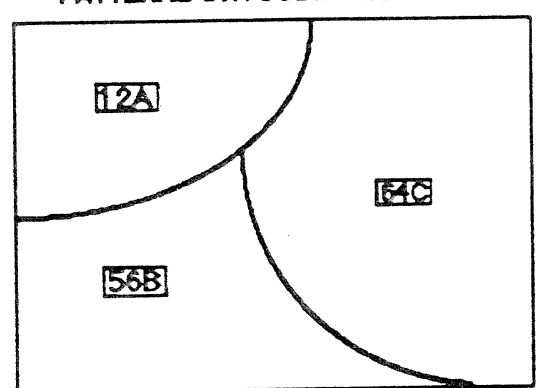

a
"REMOVNG SOL YARAEUTY BY BLOCX TREATMENTS

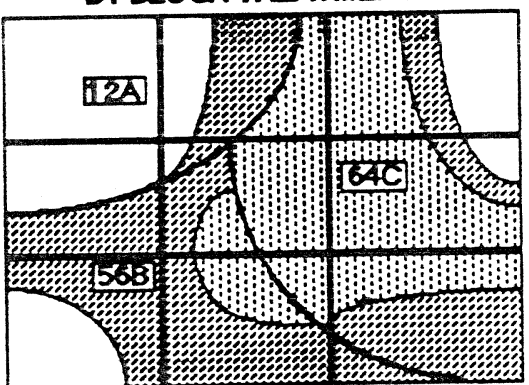

C
SOIL MAPPING UNT AND "A" HORIZON THEKNESS DISTRABUTIONS

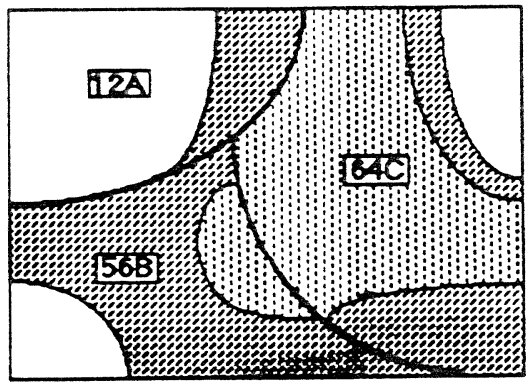

$\mathrm{b}$

"A. HOREON THAKNES S"

$<100 \mathrm{~m}$

:

$10 t 20 \mathrm{~cm}$

$>20 \mathrm{~cm}$

Fig. 1 - 8) Soll mepping unit (series) pettems in cultivetod pield. $12 A, 56 B$, and $64 C$ ore designations for different phases of a soll series.

b) Soll mapping unit and " $A$ " horizon thickness distributions.

c) "Removing" soll variebility by block treatments.

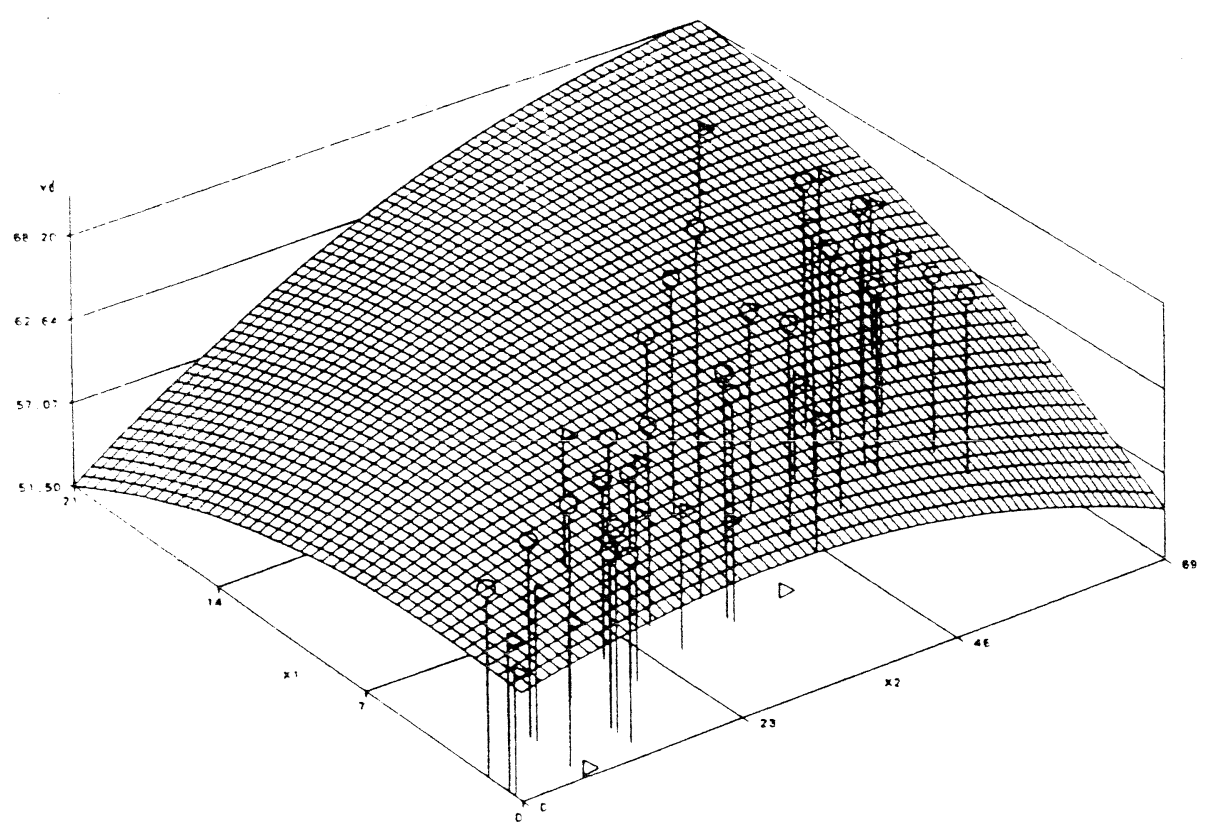

2-- Response surface for Van Meter 2 forestod site. Depth to clay

la

maximum (cm) Yd as a funct $x^{2}$ Actual soli characteristic observations are

hilslope summit $(m)$ Xl.

represented on the graphs by balloons and surface. Balloons show

observations above the response surface and flags shou observations

below the response surface. 
Table 1. Results of overall multiple regression by soil characteristic.

\begin{tabular}{|c|c|c|c|c|}
\hline Soil Property & $\begin{array}{c}\text { Overall } \\
\text { Model } \\
\text { Significance }\end{array}$ & $R^{\wedge} 2$ & $\begin{array}{l}\text { Model } \\
\text { Degree }\end{array}$ & $\begin{array}{c}\text { Site } \\
\text { Significance }\end{array}$ \\
\hline Depth to Clay Max & \# & .53 & 2 & * \\
\hline "A" Horizon Thickness & * & .30 & 2 & * \\
\hline Subsurface Horizon Thickness & * & .73 & 3 & * \\
\hline Depth to Top of "B" & * & .76 & 3 & * \\
\hline
\end{tabular}

Table 2. Response surface equations for 4 soil characteristics at 6 sites.

\begin{tabular}{|c|c|}
\hline STE & EQUATION \\
\hline & DEPTH TO CLAXMAXMUUM (cm) \\
\hline Van Meter $1+*$ & $Y_{d}=60.23+0.642 X_{1}-0.028 X_{2}-0.023 X^{2}{ }_{1}-0.003 X^{2}{ }_{2}+0.014 X_{1} X_{2}$ \\
\hline Van Meter $2+\#$ & $Y d=58.34+0.157 X_{1}+0.155 X_{2}-0.023 X^{2}{ }_{1}-0.003 X^{2}{ }_{2}+0.014 X_{1} X_{2}$ \\
\hline Dysart + & $Y d=42.30+0.638 X_{1}+0.092 X_{2}-0.023 X_{1}^{2}-0.003 X_{2}^{2}+0.014 X_{1} X_{2}$ \\
\hline Hollandt & $Y d=49.21-1.201 X_{1}-0.213 X_{2}-0.023 X^{2}-0.003 X_{2}^{2}+0.014 X_{1} X_{2}$ \\
\hline Schnable & $Y d=57.43-0.613 X_{1}+0.230 X_{2}-0.023 X_{1}^{2}-0.003 X_{2}^{2}+0.014 X_{1} X_{2}$ \\
\hline McBain* & $Y d=55.79-0.392 X_{1}-0.196 X_{2}-0.023 X_{1}^{2}-0.003 X_{2}^{2}+0.014 X_{1} X_{2}$ \\
\hline & "A" HORIZON THICKONESS (cm) \\
\hline Van Meter 1 & $Y_{2}=13.399-0.1504 X_{1}-0.0098 X_{2}+0.0008 X^{2} 1-0.0013 X^{2} 2+0.0037 X_{1} X_{2}$ \\
\hline Van Meter 2 & $Y_{2}=14.460-0.4696 X_{1}+0.0879 X_{2}+0.0008 X^{2}{ }_{1}-0.0013 X^{2}{ }_{2}+0.0037 X_{1} X_{2}$ \\
\hline Dysart & $Y_{a}=14.522-0.4551 X_{1}+0.1355 X_{2}+0.0008 X^{2}{ }_{1}-0.0013 X^{2}{ }_{2}+0.0037 X_{1} X_{2}$ \\
\hline Holland & $Y_{a}=14.576+0.0247 X_{1}-0.0732 X_{2}+0.0008 X^{2} 1-0.0013 X^{2}{ }_{2}+0.0037 X_{1} X_{2}$ \\
\hline Schnable & $Y_{\varepsilon}=14.624+0.1798 X_{1}+0.0122 X_{2}+0.0008 X^{2}{ }_{1}-0.0013 X^{2}{ }_{2}+0.0037 X_{1} X_{2}$ \\
\hline McBain & $Y_{2}=15.793-0.5806 X_{1}+0.0623 X_{2}+0.0008 X_{1}^{2}-0.0001 X^{2}{ }_{2}+0.0037 X_{1} X_{2}$ \\
\hline & SUBSURFACE HORIZON IHICKNIESS (cm) \\
\hline Van Meter 1 & $Y t=6.6627+0.3267 X_{1}+0.1718 X_{2}-0.1207 X^{2}{ }_{1}-0.0151 X^{2}{ }_{2}+0.0517 X_{1} X_{2}+0.0009 X^{3}{ }_{1}+0.0001 X^{3}{ }_{2}$ \\
\hline Van Meter 2 & $Y t=4.3652+0.2509 X_{1}+0.4863 X_{2}-0.0697 X^{2}{ }_{1}-0.0161 X^{2}{ }_{2}+0.0223 X_{1} X_{2}+0.0009 X_{1}^{3}+0.0001 X_{2}^{3}$ \\
\hline Dysart & $Y t=10.340+0.9286 X_{1}-0.1951 X_{2}-0.0345 X^{2}{ }_{1}-0.0030 X^{2}{ }_{2}-0.0170 X_{1} X_{2}+0.0009 X_{1}^{3}+0.0001 X_{2}^{3}$ \\
\hline Holland & $Y t=10.673-2.5789 X_{1}+0.4235 X_{2}+0.1089 X_{1}^{2}-0.0098 X_{2}^{2}-0.0126 X_{1} X_{2}+0.0009 X_{1}^{3}+0.0001 X_{2}^{3}$ \\
\hline Schnable & $Y_{t}=11.140+0.1965 X_{1}+0.6258 X_{2}-0.0691 X^{2}{ }_{1}+0.0188 X_{2}^{2}+0.0224 X_{1} X_{2}+0.0009 X_{1}^{3}+0.0001 X^{3}{ }_{2}$ \\
\hline McBain & $Y_{t}=13.238-0.3468 X_{1}-0.0736 X_{2}-0.0860 X_{1}^{2}+0.0115 X_{2}^{2}+0.0345 X_{1} X_{2}+0.0009 X_{1}^{3}+0.0001 X_{2}^{3}$ \\
\hline & DEPTH TO TOP OE "B" HORIZON $(\mathrm{cm})$ \\
\hline Van Meter 1 & $x_{b}=20.7217+0.07117 x_{1}+0.11955 x_{2}-0.13158 x^{2}-0.01388 x_{2}^{2}+0.06022 x_{1} x_{2}+0.00129 x^{3}{ }_{1}+0.00006 x^{3} 2$ \\
\hline Van Meter 2 & $Y \mathrm{~V}=18.9905+0.02154 X_{1}+0.44285 X_{2}-0.09888 X^{2}{ }_{1}-0.01372 X_{2}^{2}+0.03305 X_{1} X_{2}+0.00129 X^{3}{ }_{1}+0.00006 X_{2}^{3}$ \\
\hline Dyeart & $Y_{b}=26.7965+0.98240 X_{1}-0.45434 X_{2}-0.06021 X^{2}{ }_{1}+0.00486 X^{2}{ }_{2}-0.01679 X_{1} X_{2}+0.00129 X^{3}+0.00006 X^{3} 2$ \\
\hline Hollend & $\mathrm{Yb}=21.0394-0.51209 \mathrm{X}_{1}-0.02781 \mathrm{X}_{2}-0.06159 \mathrm{X}_{1}{ }_{1}-0.01003 \mathrm{X}_{2}{ }_{2}+0.03540 \mathrm{X}_{1} \mathrm{X}_{2}+0.00129 \mathrm{X}_{1}{ }_{1}+0.00006 \mathrm{X}_{2}{ }_{2}$ \\
\hline Schnable & $\mathrm{Yb}=26.9684+0.14663 \mathrm{X}_{1}+0.47890 \mathrm{X}_{2}-0.07820 \mathrm{X}_{1}{ }_{1}-0.01227 \mathrm{X}^{2}{ }_{2}+0.01761 \mathrm{X}_{1} \mathrm{X}_{2}+0.00129 \mathrm{X}_{1}^{3}+0.00006 \mathrm{X}_{2}^{3}$ \\
\hline McBain & $Y b=26.3985-0.22539 X_{1}+0.01124 X_{2}-0.06843 X^{2}-0.01059 X^{2}{ }_{2}+0.02472 X_{1} X_{2}+0.00129 X^{3}{ }_{1}+0.00006 X^{3}{ }_{2}$ \\
\hline
\end{tabular}


Table 3. Soil characteristics as predicted from response surface equations and $95 \%$ confidence inatrvalu for mean response for summit, shoulder, and backstope positions.,

\begin{tabular}{|c|c|c|c|c|c|c|c|}
\hline SITE & $\begin{array}{c}\text { SLOPE } \\
\text { POSITION }\end{array}$ & SLOPE $(*)$ & $\begin{array}{l}\text { DISTANCE } \\
\text { FROM } \\
\text { SUMMTT (m) }\end{array}$ & $\begin{array}{c}\text { DEPTH TO } \\
\text { CLAY } \\
\text { MAXIMUM (cm) } \\
\end{array}$ & $\begin{array}{c}\text { "A" } \\
\text { IORIZON } \\
\text { TIICKNESS (cm) }\end{array}$ & $\begin{array}{c}\text { SUBSURFACE } \\
\text { HORIZON } \\
\text { THICKNESS }(\mathrm{cm})\end{array}$ & $\begin{array}{c}\text { DEPTH TO } \\
\text { TOP OF "B" } \\
\text { HORIZON }(\mathrm{cm})\end{array}$ \\
\hline \multirow[t]{3}{*}{ Ven Meter 1} & Summin & 1.50 & 2.00 & $\begin{array}{c}60.96 \\
(52.71,69.20)\end{array}$ & $\begin{array}{c}13.17 \\
(11.43,14.90)\end{array}$ & $\begin{array}{c}7.31 \\
(4.63,9.98)\end{array}$ & $\begin{array}{c}20.90 \\
(18.07,23.71)\end{array}$ \\
\hline & Shoulder & 8.00 & 26.00 & $\begin{array}{c}64.07 \\
(59.59,68.54)\end{array}$ & $\begin{array}{c}11.86 \\
(10.92,12.80)\end{array}$ & $\begin{array}{c}8.78 \\
(7.18,10.38)\end{array}$ & $\begin{array}{c}20.77 \\
(19.08 .22 .46)\end{array}$ \\
\hline & Backsbope & 11.00 & 56.00 & $\begin{array}{c}60.99 \\
(49.31,72.66)\end{array}$ & $\begin{array}{c}10.11 \\
(8.35,11.89)\end{array}$ & $\begin{array}{c}8.81 \\
(6.62,11.00)\end{array}$ & $\begin{array}{c}18.72 \\
(16.40,21.04)\end{array}$ \\
\hline \multirow[t]{3}{*}{$V_{\operatorname{man}}$ Meter 2} & Summin & 0.50 & 2.00 & $\begin{array}{c}58.01 \\
(50.08,65.94)\end{array}$ & $\begin{array}{c}14.37 \\
(12.70,16.04)\end{array}$ & $\begin{array}{c}5.37 \\
(2.94,7.80)\end{array}$ & $\begin{array}{c}19.75 \\
(17.18,22.32)\end{array}$ \\
\hline & Shoulder & 8.50 & 26.00 & $\begin{array}{c}62.87 \\
(58.12 .67 .62)\end{array}$ & $\begin{array}{c}12.7 \\
(11.70,13.70)\end{array}$ & $\begin{array}{c}10.51 \\
(9.05,11.96)\end{array}$ & $\begin{array}{c}23.31 \\
(21.77,24.84)\end{array}$ \\
\hline & Backslope & 14.00 & 56.00 & $\begin{array}{c}65.52 \\
(59.41 .71 .62)\end{array}$ & $\begin{array}{c}11.76 \\
(10.47,13.05)\end{array}$ & $\begin{array}{c}8.91 \\
(7.37,10.45)\end{array}$ & $\begin{array}{c}20.92 \\
(19.30,22.55)\end{array}$ \\
\hline \multirow[t]{3}{*}{ Dysart } & Surnmit & 1.50 & 2.00 & $\begin{array}{c}43.44 \\
(35.28,51.59)\end{array}$ & $\begin{array}{c}14.1 \\
(12.38,15.81)\end{array}$ & $\begin{array}{c}11.24 \\
(8.66,13.83)\end{array}$ & $\begin{array}{c}27.22 \\
(24.48,29.95)\end{array}$ \\
\hline & Shoulder & 11.00 & 26.00 & $\begin{array}{c}50.06 \\
(42.70,57.43)\end{array}$ & $\begin{array}{c}13.34 \\
(11.79,14.89)\end{array}$ & $\begin{array}{c}7.28 \\
(4.94,9.61)\end{array}$ & $\begin{array}{c}19.62 \\
(17.15,22.09)\end{array}$ \\
\hline & Backshope & 15.50 & 56.00 & $\begin{array}{c}52.67 \\
(43.95,61.38)\end{array}$ & $\begin{array}{c}14.58 \\
(12.75,16.42)\end{array}$ & $\begin{array}{c}4.37 \\
(1.53,7.21)\end{array}$ & $\begin{array}{c}20.20 \\
(17.20,23.20)\end{array}$ \\
\hline \multirow[t]{3}{*}{ Hollend } & Surmenit & 200 & 2.00 & $\begin{array}{c}16.20 \\
(6.05,26.37)\end{array}$ & $\begin{array}{c}14.46 \\
(12.53,16.40)\end{array}$ & $\begin{array}{c}6.78 \\
(4.12,9.44)\end{array}$ & $\begin{array}{c}19.86 \\
(17.05,22.68)\end{array}$ \\
\hline & Shoulder & 10.00 & 26.00 & $\begin{array}{c}30.94 \\
(26.47,35.42)\end{array}$ & $\begin{array}{c}13.07 \\
(12.13,14.02)\end{array}$ & $\begin{array}{c}-0.46 \\
(-2.15,1.24)\end{array}$ & $\begin{array}{c}13.63 \\
(11.84,15.43)\end{array}$ \\
\hline & Backslope & 14.50 & 56.00 & $\begin{array}{c}16.35 \\
(9.84,22.87)\end{array}$ & $\begin{array}{c}10.03 \\
(8.65,11.40)\end{array}$ & $\begin{array}{c}-0.10 \\
(-2.25,2.05)\end{array}$ & $\begin{array}{c}10.18 \\
(7.91,12.44)\end{array}$ \\
\hline \multirow[t]{3}{*}{ Schmable } & Summin & 5.00 & 2.00 & $\begin{array}{c}54.27 \\
(45.96,62.58)\end{array}$ & $\begin{array}{c}13.79 \\
(12.03,15.54)\end{array}$ & $\begin{array}{c}11.79 \\
(9.30,14.30)\end{array}$ & $\begin{array}{c}26.67 \\
(24.03,29.32)\end{array}$ \\
\hline & Shoulder & 9.50 & 26.00 & $\begin{array}{c}56.73 \\
(48.84,64.63)\end{array}$ & $\begin{array}{c}13.37 \\
(11.70,15.03)\end{array}$ & $\begin{array}{c}18.39 \\
(15.85,20.91)\end{array}$ & $\begin{array}{c}31.60 \\
(28.93,34.27)\end{array}$ \\
\hline & Backshope & 29.00 & 56.00 & $\begin{array}{c}45.37 \\
(39.47,51.27)\end{array}$ & $\begin{array}{c}12.64 \\
(11.40,13.89)\end{array}$ & $\begin{array}{c}11.03 \\
(9.05,13.01)\end{array}$ & $\begin{array}{c}23.50 \\
(21.42,25.59)\end{array}$ \\
\hline \multirow[t]{3}{*}{ McBein } & Summit & 0.50 & 2.00 & $\begin{array}{c}55.77 \\
(47.95,63.58)\end{array}$ & $\begin{array}{c}15.61 \\
(13.96 .17 .26)\end{array}$ & $\begin{array}{c}12.91 \\
(9.77,16.04)\end{array}$ & $\begin{array}{c}26.27 \\
(22.66,29.89)\end{array}$ \\
\hline & Shoulder & 5.00 & 26.00 & $\begin{array}{c}48.07 \\
(43.44,52.68)\end{array}$ & $\begin{array}{c}14.09 \\
(13.12,15.07)\end{array}$ & $\begin{array}{c}6.06 \\
(4.60 .7 .53)\end{array}$ & $\begin{array}{c}21.05 \\
(19.51,22.60)\end{array}$ \\
\hline & Backsbope & 15.50 & 56.00 & $\begin{array}{c}32.12 \\
(24.33,39.91)\end{array}$ & $\begin{array}{c}9.67 \\
(8.02,11.31)\end{array}$ & $\begin{array}{c}-1.64 \\
(-4.16,0.87)\end{array}$ & $\begin{array}{c}10.05 \\
(7.39 .12 .72)\end{array}$ \\
\hline
\end{tabular}


Table 4. Means, ranges, and standard deviations of soil characteristics by slope position for the six study sites.

\begin{tabular}{|c|c|c|c|c|c|c|c|c|c|c|c|c|c|}
\hline \multirow{3}{*}{$\frac{\text { STTE }}{\text { Van Meter } 1}$} & \multirow{3}{*}{$\begin{array}{c}\begin{array}{c}\text { SLOPE } \\
\text { POSITION }\end{array} \\
\text { Summit }\end{array}$} & \multicolumn{3}{|c|}{$\begin{array}{c}\text { DEPTHTO } \\
\text { CLAY } \\
\text { MAXIMUM (cm) } \\
\end{array}$} & \multicolumn{3}{|c|}{$\begin{array}{c}\text { "A" } \\
\text { HORIZON } \\
\text { THICKNESS }(\mathrm{cm}) \\
\end{array}$} & \multicolumn{3}{|c|}{$\begin{array}{c}\text { SUBSURFACE } \\
\text { HORIZON } \\
\text { THICKNESS }(\mathrm{cm}) \\
\end{array}$} & \multicolumn{3}{|c|}{$\begin{array}{c}\text { DEPTH TO } \\
\text { TOP OF "B" } \\
\text { HORIZON }(\mathrm{cm}) \\
\end{array}$} \\
\hline & & mean & range & s.d. & mean & range & s.d. & mean & range & s.d. & mean & range & s.d. \\
\hline & & 61.6 & $45.0-98.0$ & 13.5 & 12.5 & $7.0-17.0$ & 23 & 7.7 & $4.0-11.0$ & 2.3 & 20.4 & $17.0-24.0$ & 2.4 \\
\hline \multirow{2}{*}{ Van Meter 1} & Shoulder & 64.3 & $55.0-73.0$ & 6.2 & 12.6 & $11.0-15.0$ & 1.4 & 9.1 & $6.0-14.0$ & 26 & 21.7 & $17.0-29.0$ & 3.4 \\
\hline & Backslope & 64.5 & $47.0-84.0$ & 8.5 & 10.6 & $8.0-14.0$ & 1.3 & 8.8 & $6.0-15.0$ & 2.0 & 19.3 & $15.0-26.0$ & 2.3 \\
\hline \multirow[t]{3}{*}{ Van Meter 2} & Summit & 58.0 & $27.0-69.0$ & 11.1 & 14.0 & $8.0-20.0$ & 3.3 & 8.0 & $4.0-14.0$ & 26 & 22.0 & $16.0-30.0$ & 4.0 \\
\hline & Shoulder & 63.1 & $54.0-74.0$ & 7.2 & 13.4 & $8.0-17.0$ & 2.8 & 8.6 & $7.0-11.0$ & 1.4 & 21.9 & $19.0-26.0$ & 2.9 \\
\hline & Backslope & 65.2 & $25.0-84.0$ & 13.0 & 11.5 & $7.0-19.0$ & 2.5 & 9.5 & $5.0-15.0$ & 2.5 & 21.0 & $14.0-30.0$ & 3.7 \\
\hline \multirow[t]{3}{*}{ Dysart } & Summit & 48.3 & $31.0-85.0$ & 16.9 & 15.0 & $12.0-18.0$ & 2.2 & 11.7 & $9.0-15.0$ & 2.0 & 27.0 & $23.0-31.0$ & 3.2 \\
\hline & Shoulder & 48.2 & $25.0-95.0$ & 17.3 & 15.5 & $9.0-25.0$ & 5.3 & 5.8 & $0.0-12.0$ & 5.1 & 21.2 & $10.0-26.0$ & 3.9 \\
\hline & Backslope & 48.5 & $18.0-78.0$ & 15.5 & 13.7 & $8.0-23.0$ & 4.6 & 6.1 & $0.0-16.0$ & 5.9 & 19.8 & $10.0-24.0$ & 3.8 \\
\hline \multirow[t]{3}{*}{ Holland } & Summit & 42.7 & $21.0-65.0$ & 17.0 & 14.4 & $10.0-20.0$ & 3.5 & 4.6 & $0.0-10.0$ & 5.0 & 19.0 & $15.0-22.0$ & 2.4 \\
\hline & Shoulder & 29.8 & $5.0-108.0$ & 26.0 & 13.7 & $11.0-16.0$ & 1.7 & 0.0 & $0.0-0.0$ & 0.0 & 13.7 & $11.0-16.0$ & 1.7 \\
\hline & Backslope & 21.7 & $3.5-86.0$ & 17.1 & 11.0 & $4.0-16.0$ & 2.4 & 0.0 & $0.0-0.0$ & 0.0 & 11.0 & $4.0-16.0$ & 2.4 \\
\hline \multirow[t]{3}{*}{ Schnable } & Summit & 54.9 & $47.0-61.0$ & 4.6 & 13.9 & $11.0-19.0$ & 1.8 & 14.7 & $9.0-21.0$ & 3.8 & 28.5 & $24.0-34.0$ & 3.4 \\
\hline & Shoulder & 42.5 & $11.0-75.0$ & 16.4 & 11.8 & $7.0-20.0$ & 3.6 & 12.3 & $6.0-28.0$ & 6.4 & 24.0 & $14.0-42.0$ & 7.5 \\
\hline & Backslope & 45.9 & $28.0-62.0$ & 8.7 & 13.1 & $10.0-17.0$ & 1.8 & 10.4 & $0-19.0$ & 4.7 & 23.5 & $13.0-31.0$ & 4.4 \\
\hline \multirow[t]{3}{*}{ McBain } & Summit & 51.6 & $45.0-61.0$ & 6.4 & 13.8 & $12.0-16.0$ & 1.3 & 10.4 & $9.0-14.0$ & 1.8 & 24.1 & $21.0-30.0$ & 3.0 \\
\hline & Shoulder & 53.4 & $47.0-59.0$ & 4.7 & 14.7 & $13.0-18.0$ & 1.5 & 9.6 & $0.0-19.0$ & 4.3 & 24.3 & $14.0-33.0$ & 4.8 \\
\hline & Backslope & 36.1 & $11.0-61.0$ & 13.2 & 11.8 & $5.0-17.0$ & 3.6 & 0.4 & $0.0-7.0$ & 1.5 & 12.2 & $5.0-22.0$ & 4.1 \\
\hline
\end{tabular}

